\title{
Sport - finanszírozás - eredményesség?
}

\section{Sports - Financing - Success?}

\section{Ráthonyi-Odor Kinga, Borbély Attila}

Debreceni Egyetem GTK, Sportgazdasági és -menedzsment Tanszék, Debrecen

Absztrakt: Napjainkra a sport egy több milliárdos gazdasági területté fejlódött, mely a világ egyik legdinamikusabban fejlódő ágazata és a GDP-hez is fokozatosan növekvő mértékben járul hozzá. A trendek azt mutatják, hogy ez az érték hazánkban is növekedni fog, amihez a TAO támogatás nagyon jó alapot tud biztosítani. 2010 óta a Magyar Kormány is stratégiai ágazatként kezeli a sportot, és a támogatási rendszer átalakításával az utóbbi 6 évben soha nem látott pénzügyi forrás áramlott a sportba. Érdekes és szükséges kutatási terület a befektetett többletforrások időarányos megtérülésének vizsgálata.

Jele tanulmány célja egyrészt, hogy bemutassa az államháztartás sport és szabadidós tevékenységekre és szolgáltatásokra fordított kiadásainak és a TAO támogatások mértékének változásait, másrészt, hogy elemezze Magyarország Rió-i Olimpián elért eredményességét közgazdasági megközelítésben.

Kulcsszavak: sportgazdaság, finanszírozás, eredményesség, Olimpia

Abstract: In our days, sport has improved to an economical area of billions of money, became one of the most dynamically improving sector and increasingly contributes to GDP as well. Trends show, this value would increase in Hungary too, to which TAO allowance would give a strong basis. Since 2010, the Hungarian Government also handles sport as a strategic sector and by the reform of the subsidy system never seen amount of financial source have flowed into sport. The analysis of pro rata temporize economic payback of invested surplus sources is an interesting and necessary research area.

The aim of this research on one hand is to demonstrate the changes of the amount of TAO allowances and the expenditures of public finance spent on sport and leisure activities and services. On the other hand to analyze the efficiency of Hungary in Rio Olympics in an economical point of view.

Keywords: sporteconomy, financing, efficiency, Olympics

\section{Bevezetés}

A sport napjainkban egy több milliárdos gazdasági terület, mely a világ egyik legdinamikusabban fejlődő iparága. Az uniós tagállamokban 5\%-hoz közelít a sportgazdaság GDP-hez való hozzájárulása, míg Magyarországon ez 1-1,5\%. A trendek azt mutatják, hogy ez az érték hazánkban is növekedni fog, amihez a TAO támogatás nagyon jó alapot tud biztosítani. Elmondható továbbá, hogy a TAO támogatások révén megvalósult infrastrukturális fejlesztések hosszútávon a nemzet egészségügyi rendszerére is komoly hatással lehetnek.

A Kormány 2010-ben stratégiai ágazattá tette a sportot. A bevezetett intézkedések hatására például 5\%-ról 15\%-ra nőtt a rendszeresen sportolók aránya és a támogatási rendszer átalakításával az utóbbi 6 évben soha nem látott pénzügyi forrás áramlott a sportba (Kozmann, 2016).

A Kormány értékelte az elmúlt olimpiai ciklus során a kormányzat által biztosított finanszírozási programok sportszakmai megvalósulását, mely felülvizsgálat eredményeként döntöttek arról, hogy az állami sportirányítás és a civil sportirányítás közötti feladat és hatáskörmegosztás újraszabályozása szükséges (Magyarország Kormánya, 2016).

A fent leírtak is alátámasztják, hogy érdekes és szükséges kutatási terület a befektetett többletforrások időarányos megtérülésének vizsgálata.

A tanulmány elkészítése során az alábbi célokat 
fogalmaztuk meg:

1. Az államháztartás sport és szabadidős tevékenységekre és szolgáltatásokra fordított kiadásainak bemutatása.

2. Az egyes években nyújtott TAO támogatások mértékének ismertetése.

3. Magyarország Rió-i Olimpián elért eredményességének elemzése közgazdasági megközelítésben.

\section{Anyag és módszer}

Célkitűzéseink megvalósításához a Nemzetgazdasági Minisztérium statisztikai adatait, a Költségvetési Tanács Titkárságának dokumentumait, a Közgazdász Vándorgyủlés Sportközgazdaságtani Szakosztályában elhangzott előadás eredményeit és statisztikai adatbázisok adatait használtuk fel és elemeztük.

\section{Eredmények}

Eredményeinket célkitűzéseink mentén ismertetjük. Első célkitűzésünk alapján, azállamháztartás sport és szabadidös tevékenységekre és szolgáltatásokra forditott kiadásainak bemutatására vállalkoztunk.

2010-ben az államháztartás konszolidált funkcionális kiadásainak mintegy 0,5\%-át (73 mrd Ft) fordították sport és szabadidős tevékenységekre, szolgáltatásokra (Kovács, 2015). A tervek szerint ez az arány 2015-re elérte volna az 1\%-ot (kb. 160 mrd Ft), de a tényadatok $0,7 \%$-os $(130 \mathrm{mrd} F t)$ részesedését mutatják a sportnak az összkiadásokból. Várhatóan 2016-ban megvalósul a tervezett 1\%os támogatási arány. Összességében elmondható, hogy valamennyi területen növekedett a támogatások aránya 2010-2015 között, 0,5 - 3-4\% közötti mértékben.

A központi költségvetés összes fejlesztési célú kiadásain belül vizsgálva a sport célú fejlesztések arányát (1. ábra) elmondható, hogy az elmúlt 5 évben szignifikáns növekedés következett be, hiszen 1,26\%-ról 7,81\%-ra emelkedett a fejlesztési források aránya. 2013-ban ugrásszerű növekedés volt megfigyelhető 2,11\%-ról 7,08\%-ra, majd a következö évben újabb, közel 1\%-os emelkedés volt tapasztalható.

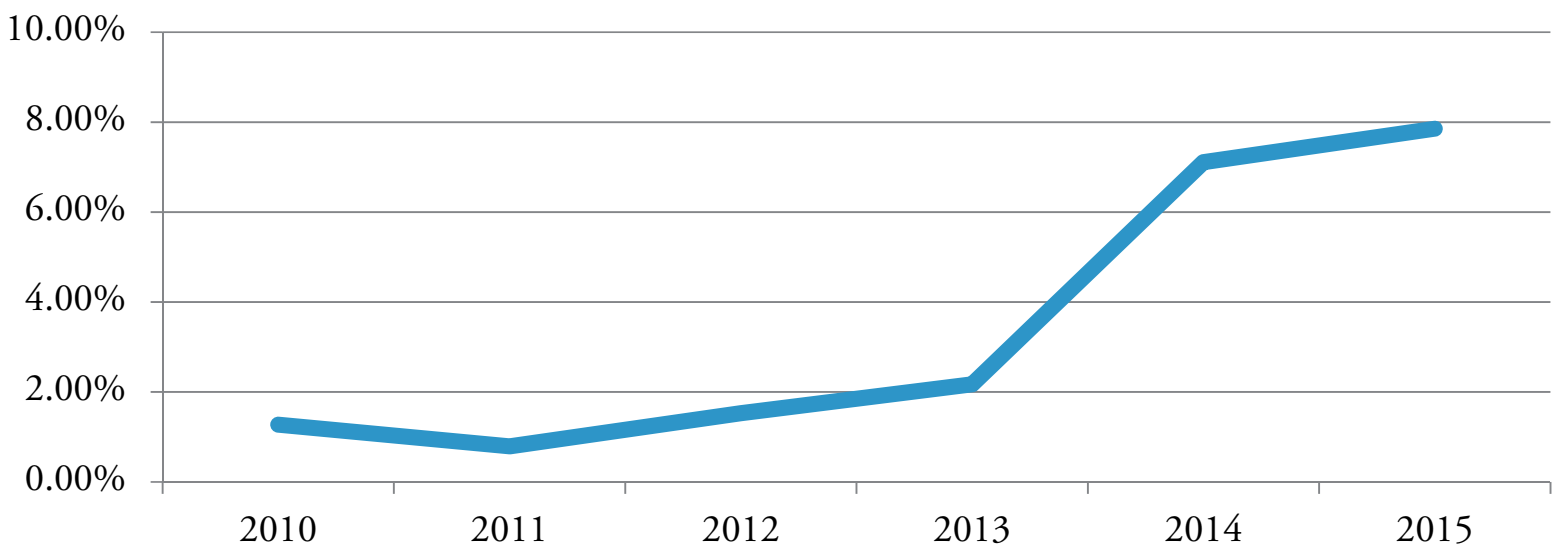

1. ábra. Sport célú fejlesztési kiadások aránya [Forrás: Kovács, 2015]

Érdekesnek tartottuk megvizsgálni, hogy 2013 után minek köszönhető a sport célú fejlesztési kiadások arányának ugrásszerü növekedése (2. ábra).

2013 után 2 év alatt 40\%-kal nőtt a jövőbeli világversenyek megrendezéséhez szükséges beruházások támogatása. A dokumentumok külön kiemelik az idei évi EYOF rendezvényt, a 2021. évi vizes világbajnokságot. Mióta azonban kiderült, hogy az idei évi vizes világbajnokságot is hazánk rendezi, a beruházások még szükségszerübbé és sürgetőbbé váltak.

2014-ben a labdarúgáshoz áramló támogatás aránya elérte a $41 \%$-ot, mely a következő évben 17\%-ra csökkent. A támogatásoknak köszönhetően 33 sportlétesítményben végeztek fejlesztéseket, támogatták az MLSZ biztonságtechnikai fejlesztéseit, vagy például a Magyar Futball Akadémia Alapítványt.

A sportintézmények fejlesztésére fordított támogatások aránya is növekedett 11\%-ról 27\%-ra. Támogatásban részesült például a 16 kiemelt sportág 
létesítményfejlesztési programja, a Magyar Sportok Háza és a Nemzeti Sportközpontok.

A fentiekkel összefüggésben lecsökkent a tofejlesztések támogatása és a sportlétesítmények PPP-s konstrukcióban történő fejlesztése. vábbi sport és szabadidős tevékenységeket szolgáló

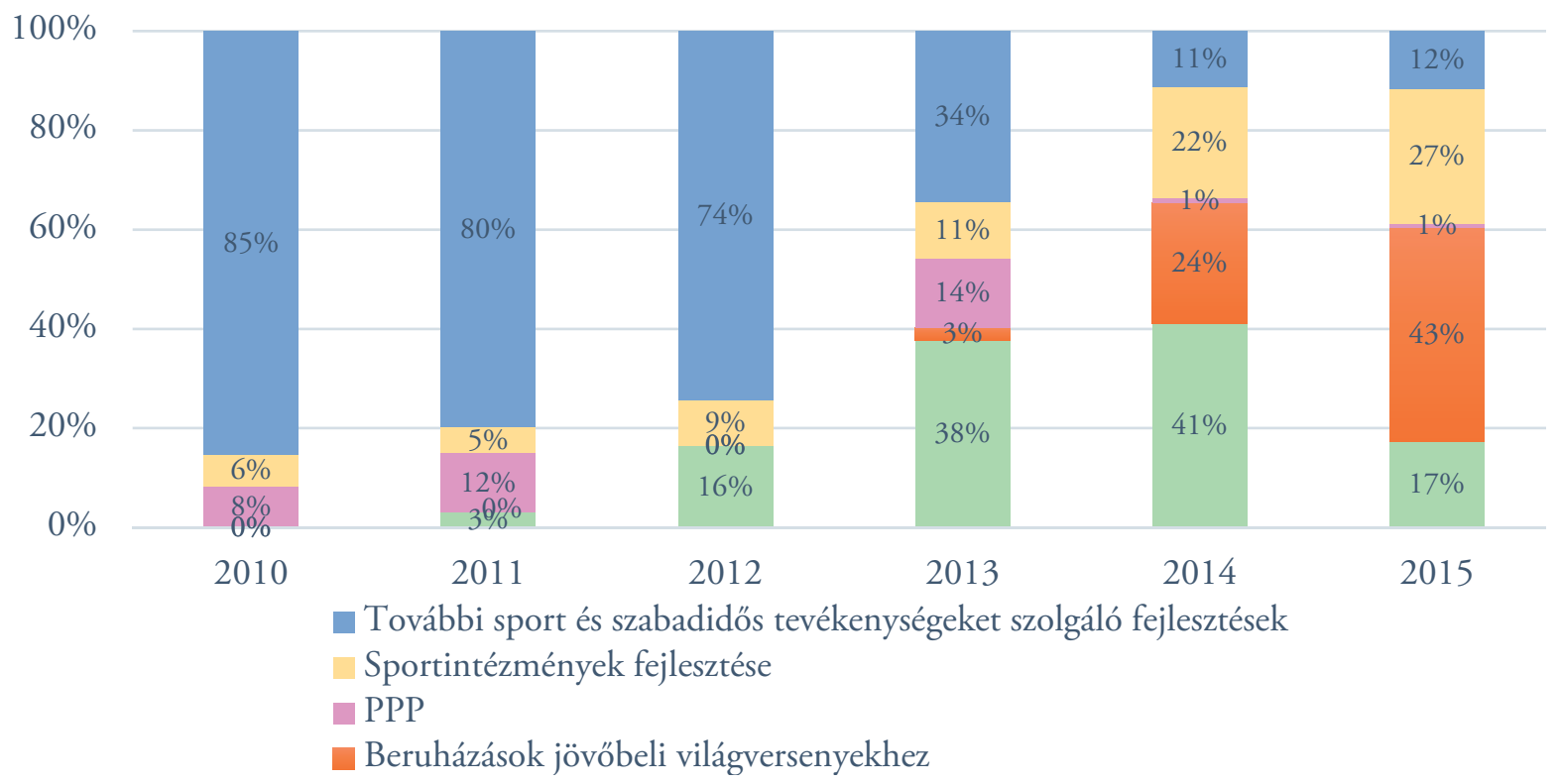

2. ábra. A központi költségvetés sport célú fejlesztési kiadásai tételesen [Forrás: saját szerkesztés, Kovács, 2015 alapján]

Második célkitűzésünknek megfelelően az egyes években nyújtott TAO támogatások mértékének alakulását ismertetjük.

A TAO támogatási rendszer indulási évében közel 30 mrd Ft támogatás áramlott az 5 látvány-csapatsporthoz, mely nagyságrend 2016-ban - az elözetes becslések szerint - elérheti a 65-68 mrd Ft-ot is (3. ábra). Természetesen ezek a számok nem tartalmazzák a reklám és szponzori tevékenységek adatait. Érdekes, hogy az önkormányzati alrendszer sport és szabadidő célú ráfordításai lényegileg nem változtak az elmúlt években, nagyjából a TAO támogatás mértékével egyeznek meg (Kovács, 2015).

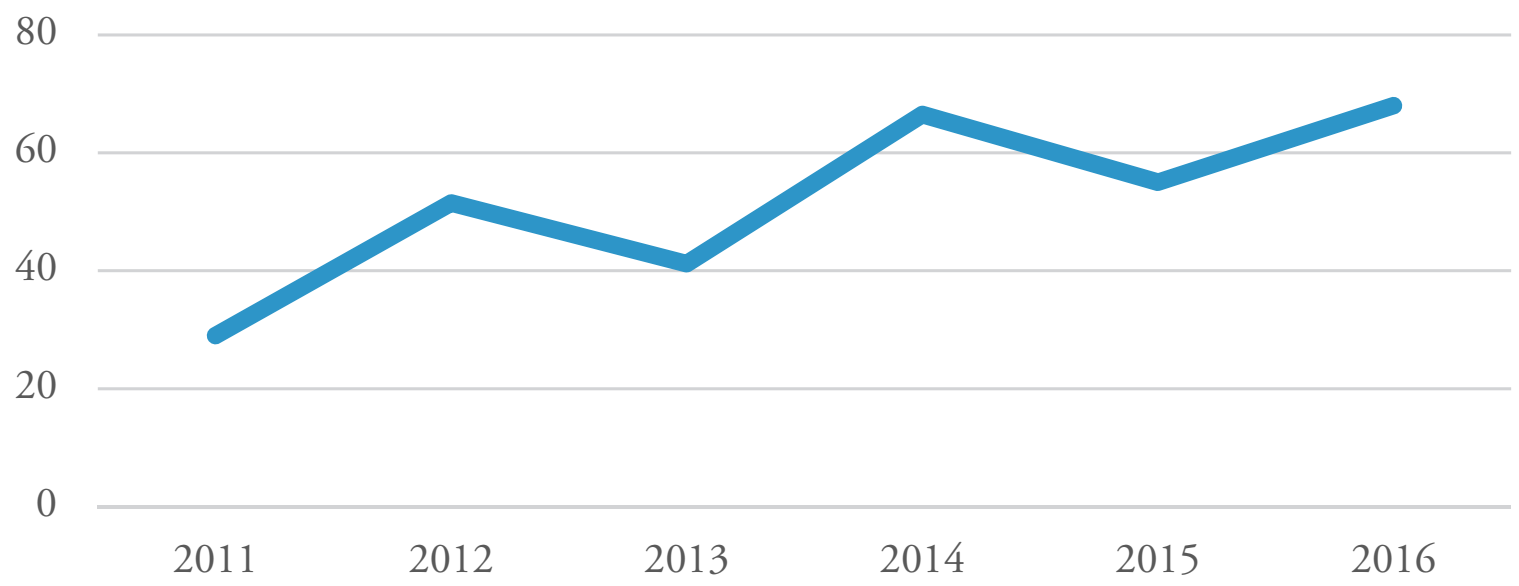

3. ábra. TAO támogatás megoszlása 2011-2016 között Forrás: saját szerkesztés, Borbély, 2016 alapján] 
A támogatás sportágak közötti megoszlásával kapcsolatban elmondható, hogy a legnagyobb mértékben $(49,4 \%)$ a labdarúgás részesül a támogatási forrásból, majd közel azonos arányban a kézilabda $(16,5 \%)$ és a vízilabda $(15,9 \%)$, őket követi a kosárlabda (11\%) és a jégkorong (7\%).

A 4. ábrán a sport célú társasági adókedvezmény aránya látható a (bruttó) társasági adóhoz viszonyítva. 2011-ben a bruttó társasági adó 7,6\%-a jelent meg sport célú társasági adókedvezmény formájában, 2015-ben ez az arány 11,3\%-ra emelkedett. Jelentős változás nem következett be a vizsgált 5 év alatt, ami valószínűleg annak köszönhető, hogy a kultúra és a művészet még nagyobb kedvezményeket kapott, és a sportra fordított támogatás arány ezért nem nőtt jelentősen.

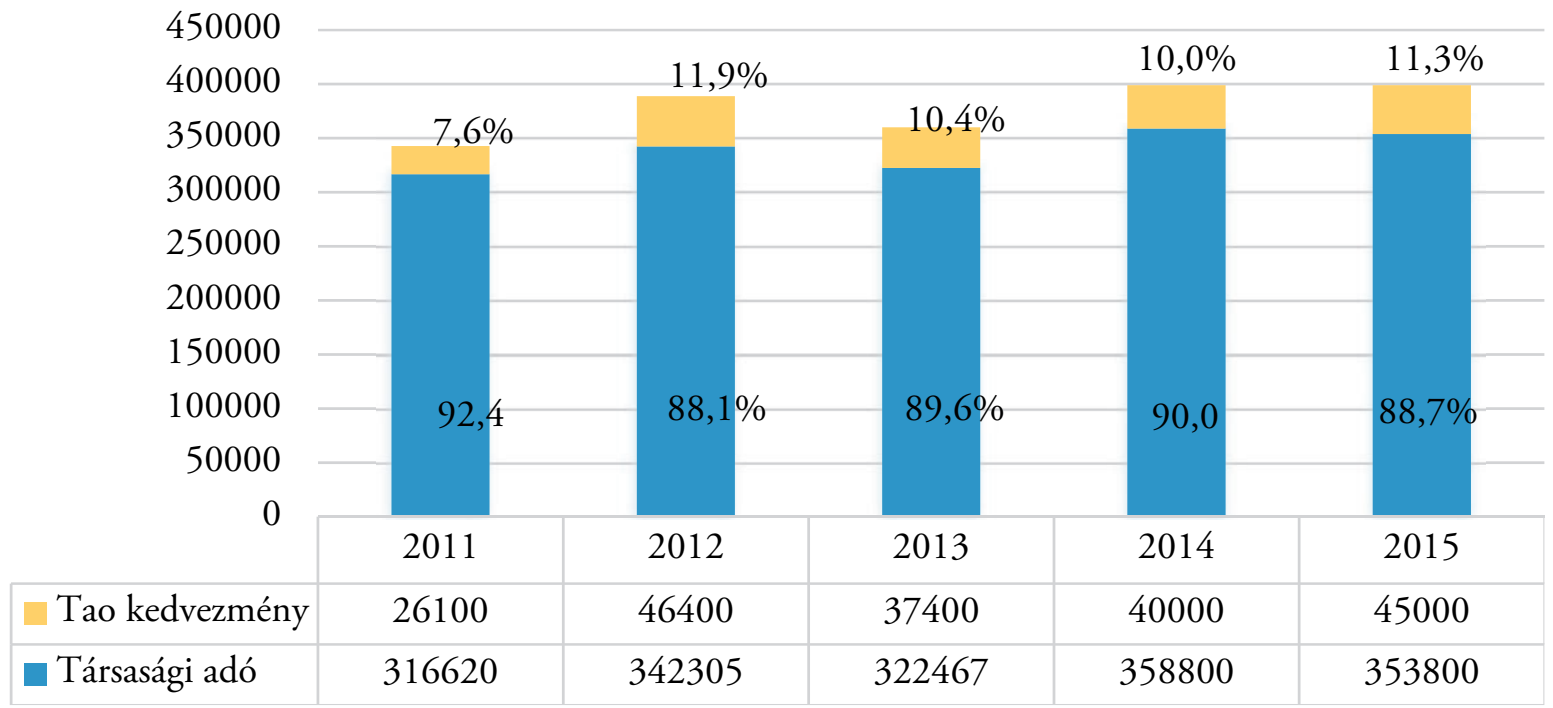

4. ábra. A sport célú társasági adókedvezmény aránya a (bruttó) társasági adóhoz (millió Ft/százalék)

[Forrás: Kovács, 2015]

Harmadik célkitűzésünknek megfelelően, $M a-$ gyarország Rió-i Olimpián elért eredményességét elemezzük közgazdasági megközelitésben.

Magyarország - adottságaihoz mérten - eredményesen szerepelt az Olimpián, hiszen a megszerzett aranyérmek számát (8 érem) tekintve 9 . helyen végzett a rangsorban. A 28 olimpiai programban szereplő sportág közül azonban csak 3 (úszás, vívás és kajak-kenu) tudott aranyérmet szerezni.

Ha az olimpiai aranyérmek számát a népességre vetítve vizsgáljuk elmondható, hogy minden 2016-os olimpiai bajnok 1 a 24 millióból. (A Föld népessége közel 7,338 milliárd fö és összesen 306 aranyérmet osztottak ki az Olimpián.) Ehhez képest hazánkban ez az adat 1 az 1,23 millióból (1. táblázat). Megállapítható, hogy a Rió-i Olimpia esetében a népesség nem túl erős magyarázó tényezője az aranyérmek számának.

A gazdasági méret és az olimpiai sikerek (érmek száma) közötti kapcsolat vizsgálata kiemelt kutatási terület a legtöbb Olimpia után. Ahhoz, hogy erre vonatkozóan általános érvényü következtetést vonjunk le, valamennyi újkori Olimpiát vizsgálat alá kellene vetni, ami igen nagy munkát jelentene. Számos tanulmány (Lachlan, 2012, Yan, 2012) foglalkozott a korábbi Olimpiai sikerek és a gazdasági méret (általában 1 före jutó GDP) közötti kapcsolat vizsgálatával. Az olimpiai játékok gazdasági és társadalmi hatásait is elemezte különböző aspektusból több kutató is (Bíró és mtsai, 2016, Müller és mtsai, 2016), melyek alapján elmondható, hogy a két tényező között közepesen erős korrelációs kapcsolat $(r>0,7)$ figyelhető meg, vagyis egy ország gazdasági ereje befolyásolja a sikeres olimpiai szereplést.

Hasonló megközelítésben vizsgálva a Rió-i Olimpiát, érdekes eredményt kapunk. Mind a népesség száma, mind a gazdasági fejlettség nem befolyásolta a megszerzett érmek számát, rendkívül gyenge korrelációs kapcsolat volt kimutatható a tényezők között. Ha a gazdasági méretet a népesség és az 1 före jutó GDP szorzataként értelmezzük, akkor ezen tényező, és a megszerzett érmek száma között viszont közepesen erős korrelációs kapcsolatot $(\mathrm{r}=0,65)$ találunk (Madár, 2016). 
1. táblázat. Olimpiai aranyérmek száma a népességre vetítve(forrás: saját szerkesztés, Internet 1 adatai alapján)

\begin{tabular}{|c|c|c|c|}
\hline Helyezés & Ország & Aranyérem & Népesség/Aranyérem \\
\hline 1 & Bahamas & 1 & 388,019 \\
\hline 2 & Jamaica & 6 & 454,323 \\
\hline 3 & Croatia & 5 & 844,880 \\
\hline 4 & Fiji & 1 & 892,145 \\
\hline 5 & New Zealand & 4 & $1,148,925$ \\
\hline 6 & Hungary & $\mathbf{8}$ & $\mathbf{1 , 2 3 0 , 5 8 5}$ \\
\hline 7 & Bahrain & 1 & $1,377,237$ \\
\hline 8 & Georgia & 2 & $1,839,500$ \\
\hline 9 & Kosovo & 1 & $1,859,203$ \\
\hline 10 & Slovenia & 1 & $2,063,768$ \\
\hline 11 & Netherlands & 8 & $2,117,065$ \\
\hline 12 & Cuba & 5 & $2,277,912$ \\
\hline
\end{tabular}

\section{Következtetések}

Összességében elmondható, hogy az államháztartás sportra fordított forrásai az elmúlt években szignifikáns növekedést mutatnak és az öt látványsport TAO-támogatása 2011-2016 között közel duplájára emelkedett.

A Riói Olimpián a 4 nyári olimpiai látványsportból csak a vízilabda kvalifikálta magát, azonban érmet nem szerzett. A nemzetek közötti versenyben Magyarország - adottságaihoz mérten - eredményesen szerepelt, de a 28 - programon szereplő - sportág közül csak 4 (vívás, úszás, kajak-kenu, atlétika) tudott érmet szerezni, aranyat viszont csak három.

Az állami pénzügyi források felhasználásának hatékonysága - időarányosan - nem igazolta a Kormányzati elvárásokat. Az elmúlt hónapokban jogszabályváltozások következtek be, módosult a sporttörvény, a pénzügyi források felhasználása az állami sportirányítás kezébe került vissza, kialakítva ezzel az egycsatornás finanszírozási rendszert ( $M a$ gyarország Kormánya, 2016).

\section{Irodalom}

1. Bíró Melinda, Müller Anetta, RáthonyiÓdor Kinga, Ráthonyi Gergely, Baloga István (2016): Az olimpiai játékok szervezésének történeti áttekintése gazdasági aspektusból. Acta
Academiae Paedagogicae Agriensis Nova Series XLIV: Sectio Sport, 5-19.

2. Borbély Attila (2016): A TAO hatása a magyar sport fejlödésére. Makrogazdasági összefüggések. Közgazdász Vándorgyülés, Kecskemét, 2016. szeptember 16.

3. Internet 1.: http://www.medalspercapita. com/ Letöltés: 2016. november 10.

4. Kovács Árpád (2015): Az állami költségvetés makro összefüggései és a sportfinanszirozás. Konferencia előadás. Debreceni Egyetem GTK, 2015. február 19.

5. Kozmann György (2016): TAO az utánpótlás-nevelés szolgálatában, sportgazdasági megközelitésben. Konferencia előadás. Debreceni Egyetem GTK, 2016. március 17-18.

6. Lachlan, James (2012): Does money buy medals? Analyzing the affect of GDP on Olympic success? http://www.yellowfinbi. com/YFCommunityNews-Does-moneybuy-medals-Analyzing-the-affect-of-GDPon-Olympic-success-117473 Letöltés: 2016. november 10.

7. Madár István (2016): A magyar olimpiai teljesitmény - Ahogyan eddig még nem láttad http://www.portfolio.hu/gazdasag/a_magyar_olimpiai_teljesitmeny_ahogyan_eddig_meg_nem_lattad.236320.html (Letöltés: 2016. november 15.) 
8. Magyarország Kormánya (2016): T/12459. számú törvényjavaslat a sportról szóló 2004. évi I. törvény módositásáról. http://www.parlament.hu/irom40/12459/12459.pdf Letöltés: 2016. november 10.

9. Müller Anetta, Bíró Melinda, Ráthonyi-Ódor Kinga, Ráthonyi Gergely, András Álmos, (2016): A sport nagyrendezvényeinek elemzése. Acta Academiae Paedagogicae Agriensis Nova Series XLIV: Sectio Sport 66-74.

10. Yan, Alexandra (2012): How A Country's GDP Relates To Its Gold Medal Count http://www. investopedia.com/financial-edge/0812/howa-countrys-gdp-relates-to-its-gold-medalcount.aspx Letöltés: 2016. november 8 . 